\title{
An Analysis of Narrators' Character and Narrative Function in The Woman in White
}

\author{
Wenjing Wang ${ }^{1}$ \\ ${ }^{1}$ School of Foreign Languages, Inner Mongolia University for the Nationalities, Tongliao, China \\ Correspondence: School of Foreign Languages, Inner Mongolia University for the Nationalities, Tongliao, China. \\ E-mail: wangwenjing128@163.com
}

Received: May 3, 2015 Accepted: May 29, 2015 Online Published: August 31, 2015

doi:10.5539/ells.v5n3p125 URL: http://dx.doi.org/10.5539/ells.v5n3p125

\begin{abstract}
The author of The Woman in White, Collins, selecting eight narrators to take turns to tell the story, hoped that the persons created by him were both of fullness in character and could take in a certain narrative function. But the better original intention of him was embodied unevenly in the novel. There are chiefly three points: firstly, some characters played a certain roles in the plot, but they were unbelievable or lacked individuality as the individuals; secondly, some characters were vivid, but they were single and odd in playing the functions of the plot; thirdly, this novel didn't do well in altering the narrators for changing the narrators doesn't go with the literature category of the detective novel. The narrative form chosen by Collins goes against the narrative effect pursued by him.
\end{abstract}

Keywords: narrator, character, narrative function, analysis

\section{Introduction}

Wilkie-Collins' The Woman in White tells a story which abounds with more complicated plots. The painter, Walter-Hart Wright, was employed to teach two young ladies to learn drawing in Limmeridge manor by the squire, Mr. Fairly. On his way to the manor, Hart Wright met a woman in white who was escaping from the mental hospital and was traced, and helped her to flee. Afterwards, Hart Wright spent a period of happy days in the manor and became good friends with Marina'Harcombe, falling in love with the other lady, Lawna-Farley. Because of Lawna's engagement, Hart Wright was forced to leave the manor painfully under the persuasion of her half blooded sister, Harcombe. Then he left Britain for a period of time. Lawna was married to the knight Percival, while the rest days of her life was so unfortunate after her marriage with Percival. After some time Percival was embarrassed by debts and he sent Lawna to the mental hospital, taking advantage of the similarity between Lawna and the woman in white in appearance, with the management of his friend, Conte Fosco. He buried the sick woman in white as Lawna and looked upon Lawna as the woman in white. After arriving in Britain from abroad, Hart Wright together with the lady, Harcombe, began to come to the rescue of Lawna and helped her to resume her identity, fighting against with and outwitting the knight Percival and Conte Fosco.

The narrative form of this novel was fresh in British literature at that moment, which opens a new writing style, having a great influence on British literature world, including the authors of Sherlock Holmes, Conan Doyle, who were enlightened by Collins. The novel is full of distinct experiment and creative spirit. Therefore, it is essential for some writers to study Collins' creative and exploring spirits in the writing techniques.

The whole story was narrated in turns by the different persons according to the time sequence, including using the written and recorded words by the narrators, the diary and some evidence materials. Just as the writer says, "when I am writing this novel, I make an experiment", it is known that the former novelists have never made an attempt to try this kind of writing. The stories in the book were narrated by the persons in the novel from beginning till ending. In the process of the development of a series of events, these narrators were arranged in various places narrating the story in turns until to the final ending." The reason for this kind of arrangement is not only to pursue the novelty of form but also to manage to make the story constantly developed forward and the content be perfect. At the same time, "the persons in the works dedicated a lot in order to push forward the development of the story and thus they have more chances to express themselves" (The Woman in White, p. 1). In a word, the writer hoped the characters depicted by him were both of fullness and undertook a certain narrative function. But in reality the better original intention of him was embodied unevenly in the works. 


\section{Narrators' Character and Narrative Function}

There are altogether eight narrators in the works who are Mr. Hart Wright, the lawyer Gilmore, Miss Harcombe, Mr. Farley, the woman housekeeper, the female cook, madam Catheric and Conte Fosco. Among the narrators, Miss Harcombe's narrating expresses her own character, being completely contrasted with the other narrators and the women appearing in the story. Harcombe's narrating started after the lawyer Gilmore left Limmeridge manor. Gilmore was Farley's family lawyer, in charge of making a document with the force of law for Lawna's distribution of property. For example, how should he make a document for Lawna to distribute her industry interest before and after her marriage. If she died, what sorts of people could have the right to inherit her property before and after she was married, and things like that. Like Hart Wright, Gilmore was also the two young ladies' loyal friend and protector, devoting to safeguard their rights all the time, but after he finished his lawyer duties, he left the manor for good. Harcombe's narrating began from her regret to the past and deep unrest to the prospect, "Mr. Gilmore says good-bye to us this morning." The male protectors left us one after another. The short and brief record expressed Harcombe's complicated feelings clearly. She and Lawna almost could not depend on anybody. Lawna was beautiful but at the same time she was unable and weak. What Harcombe had to face up with was to fight against her opponents who were more powerful and sophisticated than her, to deal with all varieties of unforeseen events, to play the role of a protector and to comfort and protect her fragile younger sister, Lawna. Although she was extremely worried, she narrated in a restrained tone in the whole account. The first sentence in the diary has shown that Harcombe realized her responsibility for the life of Lawna and her. In the following paragraph Harcombe wrote in this way, "He felt remorseful and startling without speaking directly after talking with Lawna. When we said farewell to each other, I saw his complexion and expression, worrying that Lawna revealed the secret to him and let him recognize her annoyance and my anxiety. ..." (The Woman in White, p. 130) Harcombe's observing ability was remarkable, her thinking clear, her judging accurate, her memorizing strong. On one side, her diary was an excellent female's account on the psychological level, showing her feeling and mood; on the other side, it was a complete action record between her own side and the opponent side. Her elaborate, accurate and logical recording about the events and persons provided the effective basis for her and Hart Wright to judge, infer and think for the future. In the part of Harcombe's narrative, the development of the events was clear and rule-based. In the whole diary, although she was filled with emotional turmoil and in deep turbulent sorrow and great anger, she kept a record of her own feeling and described others' behavior, all following the writing planning and arrangement, without losing her sense and judgment owing to her uncontrolled emotion.

On one side, all this was closely related to the development of the plot of the story. During the period of Harcombe's diary-keeping, she was both the eyewitness and the narrator of the whole event. She recorded the whole process from the arrangement and union of Lawna's marriage to Lawna's returning from the honey trip and settling in Blackwater park and even Percival's seizing property with conspiracy. From the outset, Harcombe didn't approve of Lawan's rootless marriage. Before wedding, Harcombe tried to maintain Lawna's rights; after marrying, Harcombe revolted against violence and hostility for Lawna's rights, facing up with threat and disrupting the plot. She was the most active actor in the story, with the plot of her diary developing about her outwitting the knight Percival and Conte Fosco.

On the other side, Harcombe's superiority in intelligence and willpower could be seen from the narrative itself, which could reveal her deep character. Conte Fosco sang high praise for Harcombe's narrating (her diary), although he acted as the planner of the whole conspiracy. After reading her diary, Conte Fosco himself was full of respect and love towards his opponent, Harcombe. "These records are amazing. I can see her quick wit, deliberate attitude, breathtaking memory, accurate observation to persons, beautiful writing style in narrative and the female intoxicating passion. All this made me worship this remarkable and noble lady, Harcombe, more beyond my description." (The Woman in White, p. 276)

The other secondary narrators' accounts more or less reflected their own character. It could be seen that the lawyer Gilmore's narrative was cautious. His viewpoints about the events expressed the old-fashioned Englishman's conservative and stereotyped character feature, showing the lawyer's well-knit and clearlyorganized thinking habit. The woman housekeeper constantly went off topic, repeatedly emphasizing her moral sense and she was the priest's widow identity. All this unnecessary feeling made her narrating stray out of the event. Being kind, the woman housekeeper took her social status and religious ideas seriously, but just as all the nagging and less-educated women, her narrative almost roughly lacked in focus and emphasis, which was loos and unwell-prepared. Mr. Farley was Lawna's uncle, two young ladies' guardian, who was selfish, cold-blooded and weak, caring for nothing except for his own "silence", feeling no sympathy for anybody except for having a pity on his own weak body, and he just thought that he did not get any peace and quiet. In the opening of his 
certification materials, Mr. Farley made a series of his feeling, "The most unfortunate thing in my life is that nobody would like to make me be peaceful. I ask everyone why he only wants to bother me. Nobody answered my question. Nobody gave me peace. All the relatives, friends, and strangers collaborated to torture me. What's wrong with me?..." (The Woman in White, p. 278) This neurasthenic poor man was half-hearted about every thing, who was not prepared to take any responsibility except that something threatened his"silence" and "poorly weak body".

In contrast, it was the protagonist Hart Wright's narrative. There was no doubt that Hart Wright was the most important person in the novel according to the narrators' narrating length and their proposition in the plot. But his narrative was pale and plane, with the impression of being shallow and superficial, and he only acted as a go-between role. This featureless hero only links up the whole story, with his brilliance far less than his opponent, Conte Fosco and the lady, Harcombe.

\section{An Analysis about Narrative Function}

Although the writer Collins' original writing intention was to make the narrators promote the story development and to display the narrators' character in the development of the plot, each narrator in the Woman in White performing unevenly. Not every narrator in the novel played these two diverse functions. There are chiefly three points for the reason.

Firstly, some characters played the roles in the plot, but they were unbelievable or lacked individuality as individuals. For example, there were a great many questions in the woman housekeeper's account. Perhaps, she could guide the readers to think more, but if people would like to think twice about her, it was hard for them to convince such a housekeeper who didn't have much schooling, but she had much doubt, constantly using suspense and questions in her statement. Mr. Farley's narrative contents were so over-exaggerated. Surely, people can appreciate that the layout of the novel required him to do so, but if people want to consider him as an individual character, it is hard for them to conceive of Mr. Farley, a selfish and shrewd narrator, who was described as a person lacking individuality. The protagonist, Hart Wright, who witnessed and participated in the whole process of the entire story from beginning to ending, was dull and stereotyped, but he himself was uncharacteristic, and it was hard for him to impress readers deeply and thoroughly.

Secondly, some characters were vivid, while they were single and odd in playing the function of the planned plots. For instance, although Harcombe's narrative accounting showed her individual character marvelously and vividly, she was not the narrator throughout the whole plot, only to narrate the story she had experienced, without charging and governing the narrative function of the whole story.

Thirdly, not only in order to set up more doubts and suspense, to lay out mystery, to pursue the brilliant and ingenious plots, like all the other detective novels, all plots linked closely, rationally precise, but also to seek the psychological depth and the three-dimensional characters and multidimensional, thus, the writer of the novel was immersed in the double-operation dilemma. The changing of the narrative perspective was either the successful factor of the works or the root of its failure, either making a person be vivid only because of the confession and the inner fluctuation (like Harcombe) or making the novel no novelty probably owing to their letting out the truth too much (like Hart Wright).

The narrators told the story one by one in turns in The Woman in White, which was novel in the form, but the narrative advantage wasn't expressed completely in altering the narrative perspective. The advantage of changing perspective could not be embodied in setting up suspense of the detective novel. The reason was that a narrator's question, speculation and inference maybe were not the suspense for the other narrators. In other words, the narrative effect was completely various in the same story which was told by the other different narrators.

\section{Conclusion}

The properly-used and excellent instance about changing narrators is Faulkner's novel, the Sound and the Fury, which was also required to adopt more people to take part in and narrate in the plot. The narrative form of it is similar with the narrative form of the Woman in White, but the difference lies in that Faulkner broke out the traditional writing methods according to the time sequence, with the events narrated by each narrator by overlapping each other. So the story is narrated from four perspectives, each one increasing the depth and implication for the novel. Each narrator's accounting both expresses himself and each other; furthermore, this variety of expression not only remains on the level of facts and truth. In a word, the greatest contribution of Faulkner's novel is to explore both aesthetic and morals in converting the perspective of narrative. The readers are involved in the story, having an intelligent contest with those incomplete messy and even selfish false 
accounting, at the same time exploring the truth of psychology and moral even existence and life.

Certainly, there also exists the suspense in Faulkner's works, like the unclear narrative of the idiot, the false narrative of the selfish people, but which is quite different from the suspense laid by Collins, where the suspense is about unclear action of persons, unclear reference of words, unclear identification and how to debunk the plot, something like that. It is obvious that the two suspense novels belong to two various types. Thereby, as to the works of Faulkner, altering the narrative perspective increases the character's psychological depth and readers' reading difficulty. While as for the works of Collins, it is likely that the latter narrator could explain the doubt made by the former narrator. These narrators cut each other down, which makes readers difficult to preserve enough respect about their mental ability, but the secret of the mysterious novel lies in the doubt.

Therefore, as for a novel in which the writer tries to put forward questions and settle questions, with well-knit and intricate plots, altering the narrators not only does not add color to the novel, but also reduces the questions when readers have in reading. On the other side, if the writer manages to make the works exploratory, deep, complicated and meaningful, to make people more sided, the detective stories are not the most appropriate literature form. The author of The Woman in White, Collins, whose purpose of writing creation was good, but at the same time this creation purpose itself includes some incompatible ingredients. The characters in the detective novel don't possess moral depth and psychological depth. The narrative way selected by Collins is against the narrative effect pursued by him. Although the narrative form is novel, with the narrators telling the stories one after another in The Woman in White, altering the narrative perspectives is not performed quite completely. The advantage of transforming narrative perspective does not conform to setting suspense and doubt in the detective story, for a certain narrator's questions and inferences maybe are not the suspense and questions to another narrator. In other words, the narrative effect of the same story which is told by different narrators is completely like chalk and cheese.

\section{References}

Aristotle. (1962). The Poetics. The People'S Literature Publishing House.

Booth, W. C. (1987). The Rhetoric of Fiction. Peking University Press.

Collins, W. (2007). The Woman in White. ShangHai Translation Press.

Frye, N. (1998). On Criticism. Baihua Literature and Art Publishing House.

James, F. L. (2002). Narrative as Rhetoric: Skill, Reader, Ethics, Ideology. Peking University Press.

Kerr, D. (2000). British Fiction and the Scene of the Crime. Foreign Literature.

Lancer, S. S. (2002). Fiction of Authority: Women Writers and the Narrative Voice. Peking University Press.

Lane, M. (2006). Multiple Interpretations of Literary. Works Peking University Press.

Oster, P. (2007). Oracle Night. YiLin Press.

Shen, D. (2004). The Study on Narratology and Stylistics of Fiction. Peking University Press.

Xu, Q., \& Huang, X. H. (2004). Several Female Images in the Woman in White. Journal of Han Shan Teacher's College.

Zhang, L. X. (2006). The tao and logic gus: east and west literary hermeneutics. Jiangsu Education Publishing House.

\section{Copyrights}

Copyright for this article is retained by the author(s), with first publication rights granted to the journal.

This is an open-access article distributed under the terms and conditions of the Creative Commons Attribution license (http://creativecommons.org/licenses/by/3.0/). 